This work is licensed under a Creative Commons Attribution 4.0 International License.

Ovaj rad dostupan je za upotrebu pod licencom Creative Commons Imenovanje 4.0 međunarodna.

UDK 821.111(73).09 Bradstreet, A.-1

Sihem GARROURI

Department of Languages and Translation

Northern Border University

Rafha, Saudi Arabia

sihem.garrouri@gmail.com
Izvorni znanstveni članak

Original Research Article

Primljeno 28. lipnja 2020.

Received: 28 June 2020

Prihvaćeno 4. rujna 2020.

Accepted: 4 September 2020

\title{
MYTHOLOGIZING THE MEMORY OF GLORIANA
}

\begin{abstract}
Consideration of Anne Bradstreet's poem "In Honour of That High and Mighty Princess, Queen Elizabeth, of Most Happy Memory" (1643) draws our attention to the paramount significance of mythical imagery in shaping Elizabeth I's posthumous reputation. The examination of this poem illustrates the ways in which Elizabeth's memory is glorified and discusses the elegiac mythical reconstruction of her image by what Schweitzer aptly labelled a "gendered poetic voice" (307). This project shows that the poet makes good use of myth to write Elizabeth's afterlife image. It scrutinizes Bradstreet's mythological depiction of the last Tudor monarch, Queen Elizabeth I, illustrating how a woman poet rewrites the identity of a female sovereign. A close analysis of various mythical, elegiac images celebrating Elizabeth allows us to evaluate Bradstreet's contribution to her myth-creation. It examines three mythical representations: Elizabeth as an incomparable leader, a Phoenix Queen, and a warrior Amazonian monarch.
\end{abstract}

Keywords: Anne Bradstreet, Elizabeth I, glorification, memory, myth, representation. 


\section{Introduction}

Artists continued to reshape and reinvent Queen Elizabeth I's reputation. Immediately after her death, courtiers, poets, and playwrights expressed their attitude to her loss in their poems, plays, and pamphlets to avoid civil strife and political revolt. This means that literature played a key role in such a transitional period. Bradstreet's poem "In Honour of That High and Mighty Princess, Queen Elizabeth, of Most Happy Memory," which was written forty years after Elizabeth's demise, gives evidence that literature has played a central role in creating Elizabeth's memory and shaping her identity. Heisch postulates that Queen Elizabeth I "did little to inspire other women to regard themselves with pride or to persuade men to regard them differently" (54); however, Bradstreet's elegy is an adequate refutation of this assertion. Indeed, being under her spell, she relies on a mythical discourse to draw attention to woman's potential.

This essay focuses on the mythical depictions of Gloriana. Although Schweitzer overtly states that Bradstreet "reproduced the major cultural myths" (303) about Queen Elizabeth, she does not offer a thorough exploration of these mythical depictions. This work will demonstrate how Anne Bradstreet, a woman poet, used the startling strategy of mythical depictions to eternalize the Queen's memory and highlight her accomplishments. It also seeks to prove that the language is carefully chosen to play a crucial and effective role, glorifying Elizabeth's memory. Moreover, Bradstreet's poem provides the most compelling examples of this phenomenon of myth-creation of Elizabeth's afterlife image.

Elizabeth I was cognizant of her vulnerability as a single female monarch. For this very reason, she cautiously and brilliantly fashioned her image as a mighty Queen who posed no threat to patriarchal gender expectations. She should have realized that self-fashioning was essential for a female sovereign. She, unquestionably, played a vital role in her image-making by displaying several inconsistent images based on classical mythology as an effective instrumental device to negotiate both gender and identity. In addition, she exploited all mediums available to solidify and legitimize her female sovereignty. Accordingly, she ended up creating different identities as manifested in her numerous names: Deborah, Gloriana, Cynthia, Good Queen Bess, Astraea, the Virgin Queen, and the Fairy Queen. Hence, it would be misleading to assume that Elizabeth has one fixed image; she is a variety of representations, an example of "the fractured, multiple sites of identity" or "multi-layered personas" (Alfar 55). The multiplicity of 
images not only illustrates Elizabeth's care for her public persona but also it laid the foundation for her myth and paved the way for subsequent representations. Furthermore, and perhaps most importantly, Bradstreet appears to utilize Elizabeth's strategy of mythological representation to resist the patriarchal society that devalued women's abilities. Her aim seems to give voice to women, in general, and gain credibility for her poetic talents, in particular.

We would suggest that Bradstreet relies on mythology to give supportive evidence about Elizabeth's radiant splendour. A considerable number of studies have focused on the gendered implications of the poem such as Schweitzer, Gim, and Engberg; however, neither scholar adequately traces a thorough scrutiny of Bradstreet's mythical discourse and its rhetorical power as an influential approach to assert the validity of female power. Simply put, mythological allusions are powerful devices or highly consequential mediums in the recreation of Elizabeth's memory.

Before addressing Bradstreet's mythical imagery, it is vital to briefly define myth as a complex, ambivalent term that is derived from the Greek word mythos and means a statement, a story, or a tale. There are various definitions of myth ranging from traditional stories, symbols, narratives, "a way of seeing" (Latham 32 ) to a "deliberately deceptive invention" (Raymond Williams 211). Edson postulates that myth is a complex cultural reality (147). Freeman and Doran define a historical myth as "a widely held interpretation of historical events that is believed, not for its veracity, but because it explains the past in a way that somehow satisfies the worldview of those who believe it" (2). As a "socio-cultural narration," it offers an explanation of the social practices, beliefs, and customs and enhances the uniqueness of the community, and reinforces "cultural continuity" (Edson 147-48). More importantly, however, myth is considered by the society in which it is recounted as "both sacred and true" (Doty 14). In this paper, the term myth will be used as an elaborate story or conviction and a way of giving identity and creating an acceptable historical persona. The use of a mythical discourse allowed Bradstreet to project Elizabeth's political persona and rewrite her memory. It is a strategic approach of resisting trivializing and ignoring women's potential. Edson claims that myths have various functions including reinforcing the uniqueness and veracity of an event, disclosing "the sacred history of people," explaining a phenomenon that is crucial for the stability of the community, and conveying models for social acceptability (147). We would argue that mythic rhetorical implications allowed the poet not only to foster her claims about 
Elizabeth and crystallize her image but also to gain credibility as a talented female poet. Bradstreet cleverly conveys the most familiar myths about Elizabeth such as the Virgin Queen, a divinely ordained monarch, a warrior monarch. This project offers an examination of three mythical delineations: Elizabeth as an exceptional Queen, a phoenix sovereign, and a warrior leader.

\section{“Our Queen Is No Fit Parallel”}

Bradstreet praises the queen, highlights her elevation and unique status, and depicts her as an ideal, incomparable figure. She foregrounds her charisma and celebrates her female authority:

Full fraught with honour, riches and with day[s,]

She sat, she set, like Titan in his rayes.

No more shall rise or set so glorious sun

Until the heavens great revolution.

If then new things their old form shall retain,

Eliza shall rule Albion once again. (Bradstreet 47)

Using simile, she overtly compares Elizabeth to "Titan in his rayes." This reference to Greek mythology presents Elizabeth as a god-like figure. Bradstreet flatly states that Elizabeth's rule is the best since it brings wealth, happiness, and freedom to the English people. To reinforce this idea, she uses the metaphor of "the glorious sun." By comparing her with the sun-God Titan, who challenged the Olympian authority, and employing the imagery of rising and setting, Bradstreet excitingly advocates the idea that Elizabeth "would rise again to reinstitute a gynocentric renascence" (Schweitzer 306). Here, the idea of resurrection is manifested through the repetition of "shall."

Bradstreet introduces Elizabeth as a heroine: all-glorious, all-virtuous, and an incomparable sovereign. She looks back on Elizabeth's reign with admiration and fondness: "who was so good, so just, so learn'd, so wise, / from all the kings on earth she won the prize" (Bradstreet 45). Using hyperbolic imagery, the poet depicts Elizabeth as the best ever ruler. It seems safe to argue that the repeated /s/ and /z/ sounds in these two lines reveal a state of meditation, as though the poet were subtly asking us to be silent so that we could pay attention to Elizabeth's distinct qualities: goodness, fairness, knowledge, and wisdom. These attributes are underlined through the use of apotheosis (Hildebrand 118) and the 
repetition of the adverb of degree "so." Accordingly, she deliberately recreates a distinctive, exaggerated image. She addresses her male audience,

Nay Masculines, you have thus taxt us long,

But she, though dead, will vindicate our wrong.

Let such as say our Sex is void of Reason,

Know tis a Slander now, but once was Treason.

But happy England, which had such a Queen;

Yea happy, happy, had those dayes still bean;

But happiness lyes in a higher sphere,

Then wonder not Eliza moves not here. (Bradstreet 47)

As Lisa Gim points out, although the poem is an elegy, it does not convey the internal experience of grief; instead it celebrates the triumphs of a mighty Queen and presents a utopian image (177). However, the melancholic tone caused by male suppression is, possibly, manifested through the use of assonance: the repetition of the same vowel sound in "masculine," "thus," "us." Employing polyptoton by using the word happy as both an adjective and a noun, she emphatically praises the reign of Elizabeth. She also uses personification "happy England" to stress the splendour of her age. Moreover, the repetition of the conjunction "but" foregrounds the contrast between men's expectations and Elizabeth's achievements. In other words, although males denied women's ability to effectively play any public role, Elizabeth proved a successful leader. The prosperity and richness of her kingdom emphasizes the greatness of Elizabeth's reign. Consequently, she is a model of feminine recognized success. In Engberg's words, Bradstreet "secures Queen Elizabeth's fame" (32):

No Phoenix Pen, nor Spencers poetry,

No Speeds nor Cambaens learned History,

Elizahs works, warrs, praise, can e're compact,

The World's the Theatre where she did act.

No memoryes nor volumes can contain

The 'leven Olympiads of her happy reign. (Bradstreet 44-45)

Bradstreet evidently places Elizabeth at a higher level far from being fully covered either by Spenser's literary works or by Camden's histories or any other manuscripts. To make this idea clear, she uses repetitive similar structures: "no phoenix," "no Speeds," "no memoryes" and "nor" Spencer’s Faerie Queene, "nor" 
Camden's The History of the Most Renewed and Victorious Princess Elizabeth Late Queen of England, "nor volumes." The poet explicitly acknowledges her failure to accurately encompass the reign of Elizabeth. She confesses her inability to convincingly offer a compelling depiction of Elizabeth's merits: "But time would fail me, so my tongue would to[o], / to tell of half she did, or she could doe." This denial of ability to adequately depict her, casts Elizabeth "as existing somewhere above and beyond" (Hackett 187). Above all, the Queen's greatness is similar to Christ's in making England a prosperous kingdom and resurrecting (Gillespie 224). Ostensibly, this apology is meant to cast her as a unique figure. This is a particularly cogent example of creating a mythical representation of a Queen whose achievements are far from being covered. She is presented as a mighty, powerful leader whose greatness best illustrates women's capabilities once given the opportunity to act in the public sphere. Obviously, the creation of a magnificent, legendary image rendered Elizabeth an elusive character far from being adequately defined. She further refers to the metaphoric imagery of the world as a theatre: "The World's the Theatre where she did act" (Bradstreet 45). Elizabeth was also aware of the significance of performance as a strategic device to maintain royal power. This is evident in her letter to James, the King of Scots, in 1594: "We princes are set on highest stage, where looks of all beholders verdicts our works" (qtd. in Marcus et al. 383).

The choice of terms such as "perfections," "incomparable," "wealth," "riches," and "glorious" underlines the idea that Elizabeth's rule was splendid. Bradstreet asks her readers a number of questions: "Was ever people better rul'd then hers? / Was ever Land more happy freed from stirrs? / Did ever wealth in England more abound?" (Bradstreet 45). Probably, the poet not only wants to prove her uniqueness and highlight her superiority and elevation but also expresses her admiration for a woman leader who performs effectively the masculine duty of leadership associated with male attributes in early modern England. By transcending the traditional patriarchal society, Elizabeth silenced male's scepticism and criticism of female sovereignty. Indeed, critics as John Knox viewed women as "weak, frail, impatient, feeble and foolish ... inconstant, variable, cruel, and lacking the spirit of counsel and regiment" (9).

More intriguing, Bradstreet explicitly claims that Elizabeth created great men:

Nor men nor Coyn she spar'd to do them good. 
The rude untamed Irish she did quel.

Before her picture the proud Tyrone fell.

Had ever prince such Counsellours as she?

Her self Minerva caus'd them so to be.

Such Captains and such souldiers never seen,

As were the Subjects of our Pallas Queen. (Bradstreet 46)

As evident in these lines, Elizabeth is depicted as the creator of great soldiers and counsellors. Additionally, by establishing a comparison between Elizabeth and Minerva or Pallas Athena, Bradstreet seemingly foregrounds Elizabeth's qualities of wisdom, intelligence, and morals. Indeed, "Athena is revered as the Goddess of War and Peace, the Goddess of Wisdom, patron of arts and crafts, and guardian of cities ... the inventor and protector of culture and as the protector of civilized life and agriculture" (Prophet and Prophet 267). The reference to Greek and Roman mythology is meant to put emphasis on her achievements, which match Minerva's accomplishments. As Pallas Queen, she encouraged her subjects to achieve greatness in governmental, intellectual, military, artistic, and political spheres. Obviously, this mythical imagery projects an extraordinary, superb female leader who is the creator of influential people and a golden age. Accordingly, Bradstreet intensified Elizabeth's image and enhanced her myth.

Apart from being the cause of her subjects' greatness, she is also at the heart of their spiritual life. Bradstreet further presents Elizabeth as a unique figure who is better than "her contemporaries or historical-mythical figures" (Bono 125):

Dido first Foundress of proud Carthage walls, (Who living consummates her Funeralls),

A great Eliza, but compar'd with ours,

How vanisheth her glory, wealth, and powers.

Profuse proud Cleopatra, whose wrong name,

Instead of glory, prov'd her Countryes shame:

Of her what worth in Storyes to be seen,

But that she was a rich Egyptian Queen.

Zenobya potent Empress of the East,

And of all these, without compare the best,

Whom none but great Aurelius could quel; 
Yet for our Queen is no fit Parallel.

She was a Phoenix Queen, so shall she be,

Her Ashes not reviv'd, more Phoenix she. (Bradstreet 46-47)

The glory of Dido, the founder of Carthage, is incomparable with that of Elizabeth. As Williams points out, Elizabeth's connection with Dido is partially explained by her name "Elissa," which was replaced by Dido, which means having the qualities of courage, perseverance, and determination, as well as reflecting on her adventurous roaming (Deanne Williams 33). Indeed, she travelled to Northeast Africa where she built Carthage, a powerful, expansionist empire that competed with the Roman Empire. Like Dido, Elizabeth is a mighty, tenacious, brave leader. Bradstreet, furthermore, postulates that Elizabeth's attainments surpassed the achievements of Zenobia, the Empress of the East. The magnificence and splendour of Elizabeth's reign also outshines Cleopatra, the Egyptian Queen, whose life and reign is also subject to mythology. Such unrealistic hyperbolic depiction reveals the significance of Bradstreet's mythical approach. The poet evidently professed her enthusiasm for Elizabeth by underlining her elevation and her outstanding position. Her admiration is manifested in claiming that she is an exceptional woman leader. The loftier superlative "the best" and the negative forms, "without," "none," "no," "not," are telling in the sense that they transform Elizabeth into a sublime, magnificent figure.

Bradstreet also compares Elizabeth with Semiramis, the Amazon Queen of Assyria, a mythological figure who held a unified empire:

Semiramis to her, is but obscure,

More infamy then fame, she did procure.

She built her glory but on Babels walls,

Worlds wonder for a while, but yet it falls. (Bradstreet 46)

According to Bradstreet, Semiramis' fame did not measure up to Elizabeth's reputation. Although she fascinated the world by constructing the Tower of Babel, which is a symbol of her greatness, it fell apart. Similarly, her fame fades away, while Elizabeth's popularity has perpetually increased.

It might appear obvious that Bradstreet's elegiac depiction constructs a novel legendary identity by claiming that the Queen fit no parallel. It is also ostensible that Bradstreet conceives and approaches Gloriana's rule by employing mythology as an effective medium to glorify Elizabeth's memory. Hence, mythological 
representation sets the stage for Elizabeth's fame and eases the path for her immortality. In other words, mythology is a means of disseminating images and creating personalities. While the proliferation of her image in poetry has enhanced Elizabeth's mythmaking, it surely reveals that Bradstreet blended literary devices with mythology to recreate the memory of Elizabeth.

\section{"A Phoenix Queen”}

Apart from being cast enthusiastically as an unparalleled Queen, there is substantial evidence that Elizabeth is also depicted as a mythological phoenix. The most remarkable example of this portrayal is obvious through the use of the past ("she was a Phoenix Queen") and the future ("she shall be"), which enhances her permanent legend as a Protestant champion or a providential monarch. The Phoenix is a recurrent symbol in Elizabeth's iconography during her reign. An illustrative example is the Phoenix Portrait (1575). As a Christian emblem of the resurrection of Christ, it is also linked to the Virgin Mary (Jeffrey 612). This mythical emblem was an instrumental device that allowed Bradstreet to project the image of the Virgin Queen. By associating her with Christ and the Virgin Mary, Bradstreet emphasises the idea that she was divinely-sanctioned. Additionally, the Phoenix stands for "faith and constancy" (Ferguson 23). Content contends that the phoenix is an emblem of regeneration and self-sacrifice. Elizabeth herself certainly wanted to display the image of self-sacrifice. Indeed, she represented herself as the ever-loving-mother who gave priority to the political needs of her nation and denied her personal desires (Content 245). She claimed playing a maternal role to reinforce the idea of an unconditional sacrifice for the welfare of her kingdom. Elizabeth declared that she was metaphorically married to England. This symbolic marriage gave Elizabeth an opportunity to play the role of a distinguished woman who is different from other women. Maternity implies limitless commitment and sacrifice for the interests of her people. Hence, Elizabeth's celibacy was presented as a sacrifice for her country. She had to ignore her passionate love, abandon her human qualities, deny her personal happiness, and become an icon, a Virgin Queen. Indeed, for a female leader, in the sixteenth-century context, to be a supreme sovereign, sacrifice was a necessity in order to convince her subjects of her divine role.

It is worth noting that several elegies, written after Elizabeth's demise, refer to the myth of the phoenix. She was presented as a "genuine phoenix" (Lawson qtd. in Goldring 350) and the "most worthy phoenix" (James qtd. in Goldring 
569). The phoenix is "a bird rising from the aftermath of a fire as symbolizing rebirth. The word phoenix comes from the Ancient Greek work, $\varphi$ oĩvı $\xi$, phoenix, said to be a sacred firebird with origins in several ancient mythologies" (Weber 148). According to Schweitzer, rebirth is manifested in rising from the ashes of conventional gender roles to lead England as both a virgin warrior Queen and a nurturing mother (304). It is the revival of the situation of women in general who would have a poetic as well as a historical voice by transcending gender limitations (Schweitzer 304). Bradstreet writes: "She was a Phoenix Queen, so shall she be, / Her ashes not reviv'd, more Phoenix she" (Bradstreet 47). This last line reveals that other phoenixes will rise from her ashes, a possible reference to the continuity of her Dynasty. The poet refers to the idea of rebirth, or to what Gim termed the "recuperation" or resurrection of her glorious era, which means her fame is likely not to fade away (177). Nevertheless, this is an unequivocal proof of Bradstreet's mythical rendering of Elizabeth.

According to Jeffery, the phoenix symbolizes not only resurrection but also Christ himself (612). Furthermore, the phoenix is a mythical bird known for its attractiveness and longevity. At the end of its life, it establishes a nest, which turns into flames that consumes the phoenix and a new one emerges out of ashes. Consequently, it stands for immortality (Ravenhill-Johnson and James 29) and renewal. Thereupon, it seems possible to contend that Elizabeth is presented as an immortal, Christ-like figure that brought true religion - Protestantism. Clearly, then, religious imagery was employed to cast Elizabeth as an icon - The Defender of the Protestant faith.

In fact, her political skill is also evident in her religious settlement. In the early decade of her reign, she established Protestantism as the official religion in England. Unlike her sister, Mary I, who persecuted Protestants, Elizabeth was lenient and tolerant to Catholics, though sometimes she punished believers in the Old Faith. She understood that frontal confrontation might lead to a civil, religious war. Her ability to exercise power in a deeply patriarchal society was a remarkable achievement. Her success as a female monarch is, indeed, evidence that women could effectively lead nations. And thus, she cleverly eased the path for women's emancipation.

Besides, she is still widely considered as the most influential woman in history in one of the greatest periods in the Western world. Her age is arguably the greatest in English history since she reigned during an era of extraordinary 
achievements and developments in both literature and arts. Her reign was characterized by prosperity, wealth, and a flourishing culture. She transformed England into a relatively powerful artistic and cultural centre. It witnessed a widespread increase in literacy, as well as expansion overseas, and military victory over the Spanish Armada. Indeed Shakespeare, Spenser, and Marlowe marked the Renaissance literature whereas Drake, Raleigh, and Frobisher expanded trade abroad. She encouraged voyages to the New World and the increase of the national treasury: "Her Sea-men through all straights the world did round; / Terra incognita might know the sound. / Her Drake came laded home with Spanish gold" (Bradstreet 46).

Her myth expands, particularly, because she is, "larger than life" (Ford and Mitchell 228). In addition, various stories she created, though "mutually incompatible," have "made her into a figure that is greater than the sum of all the disparate parts of her mythos" (Dobson and Watson 2). She chose not to relinquish her power as a queen while abandoning marriage plans and creating a substitute for her people, the Virgin image. Moreover, her myth flourished posthumously, possibly because of the unprecedented situation of a woman in power in an era in which women were considered inferior to men. Additionally, her fame and virtues resonated in the seventeenth century because she was a model to criticize the Stuart monarchs (Doran and Freeman 7-9). Other possible reasons for the endurance of her myth are nostalgia for a militant Protestant Champion, her appropriation of conflicting images from elite and popular culture, her gender, and her ability to transcend gender cultural boundaries and reject male domination.

\section{The Warrior Amazonian Queen}

The mythical portrayal of Gloriana as an ideal figure is also manifested in representing her as a warrior Amazonian Queen. To achieve this very purpose, the poet establishes a comparison between Elizabeth and another great mythical figure, Tomyris, Queen of the Massagetae. Tomyris is a warrior Queen who led her troops against Cyrus, the commander of the great army of Persia. Not only is her military success noteworthy but also her tenacity and perseverance, which enabled her to challenge the pride of a man who planned to be King of the Massagetae. The common feature shared by the two leaders is being Amazonian Queens who commanded their armies against their enemies who threatened to invade their territories. In the poem, Bradstreet refers to Elizabeth's appearance 
in the battlefield at Tilbury, Essex, to encourage her troops to defeat the Spanish Armada,

Fierce Tomris (Cyrus Heads-man), Scythians queen,

Had put her harness off, had shee but seen

Our Amazon in th' Camp at Tilbury,

Judging all valour and all Majesty

Within that Princess to have residence,

And prostrate yielded to her excellence. (Bradstreet 46)

It is apparent that "the memory of Elizabeth's mistakes and failures, of all the crises, disasters and problems of her 45-year reign sank into oblivion as the Armada sank into the Atlantic" (Doran and Freeman 17). The glorification of her image is also evident in foregrounding her military successes and foreign triumphs: "Her victoryes in forreign Coasts resound, / Ships more invincible then Spain's her foe / She wrackt, she sackt, she sunk his Armado" (Bradstreet 45). Onomatopoeic verbs such as "wrackt," "sackt," and "sunk" accentuate the image of the warrior Queen. By stating that she defeated the enemies who challenged her royal authority, Bradstreet, conspicuously, praises Elizabeth's military achievements as well as her political and ecclesiastical accomplishments. Evidently, Bradstreet represents Elizabeth "in idealistic, recognizably nostalgic ways" (Watkins 106). In fact, for Bradstreet, Elizabeth's merits unveil the narrowness of her own community that did not appreciate her ability to challenge the patriarchal society (Watkins 106).

Perhaps the most compelling detail in the poem are the lines "She hath wip'd off th' aspersion of her Sex, / That women wisdome lack to play the Rex" (Bradstreet 45). As evident in this couplet, Elizabeth's successful leadership proves that the stereotypical attitudes towards women as frail and lacking wisdom and courage are erroneous, a mere prejudice. The poet's argument is that Elizabeth's success shows that women can successfully govern once placed in the seat of governance. The poet plainly refers to the prevailing stereotypical attitude towards women as lacking wisdom, or what Hutchins aptly labels a "lack of $s c i$ entia" (48), thus being incapable of exercising authority. The poet is impressed by her ability to transcend gender restrictions in a male- dominated society. She seems to proclaim that women are capable of leading nations because they are as wise and brave as men, a strategic way to resist masculine contempt using her verse. Hence, Bradstreet's construction of the memory of Elizabeth I is meant to 
show women's potential, question male supremacy and female subordination, and challenge the patriarchal division of roles. By rewriting the memory of Elizabeth, the poet seemingly expresses "protofeminist female desires, ambitions and fantasies" (Gim 178).

Another elegiac representation that Bradstreet casts is being a "Protectrix" of other nations. For instance, Elizabeth secured Henry of Navarre's accession to the throne of France. Moreover, she also helped Don Anthony to succeed to the throne in Portugal and the Earl of Thyrone in Ireland. Hence, she was a peace-maker not only in England but also abroad. Accordingly, it seems logical to argue that the memory of Elizabeth is obliquely evoked not only as a reminder of English nationalism but also as an international inspirational figure illustrating the reversal of patterns of power for women in Old and New England.

In recreating the myth of Elizabeth, Bradstreet enhances the representation of Elizabeth as a warrior queen, which is certainly a great deal of exaggeration, perhaps precisely to immortalize her. Indeed, Elizabeth is known for her reluctance to declare wars. In contrast, Bradstreet celebrates the Queen's outstanding military and religious accomplishments by referring to her "victoryes." There is no doubt that the victory of Elizabeth in the Spanish Armada, which threatened to invade England in 1588, made her an embodiment of national defence and an international figure because she defeated the world's greatest power, proving that leadership is not gender limited. The poet claimed that unlike some males who are "unmanly" or without masculine attributes, Elizabeth appropriated manly qualities such as courage and intelligence. The elegist confesses that she aptly retells the story of Elizabeth: "Nor say I more then duly is her due." Above all, this can be proved as "Millions will testifie that this is true" (Bradstreet 45). Indeed, "she's Argument enough to make you mute" (Bradstreet 45). In other words, Elizabeth is an example of a great female leader who evidently silenced misogynist views. She refuted the Spanish doubts about her ability to rule by vanquishing the Spanish Armada: "Spains Monarch sayes not so, nor yet his host: / She taught them better manners, to their cost" (Bradstreet 45). This means that Elizabeth taught a lesson to those who doubted her abilities to rule effectively by her victory over Spain, the greatest power in that era that threatened to invade England.

Although the battlefield is men's field, the Queen was able to inspire her troops to face the fear of the advancing Armada and evoke patriotic emotions 
to defend their nation against tyrants. By commanding her troops, she underlined women's potential and placed the very men who doubted her abilities in a subordinate status. Clearly, then, the use of the Amazon myth allows Bradstreet to reconstruct and eternalise Elizabeth's memory and redefine masculine and feminine roles. After the defeat of the Spanish Armada, Elizabeth was delineated as Gloriana. Spenser wrote to Sir Walter Raleigh: "in that Faery Queene I meane glory in my generall intention, but in my particular I conceive the most excellent and glorious person of our soveraine the Queene, and her kingdome in Faery land" (206). Elizabeth became an embodiment of empire, church, and state, an emblem of nationalism, concord, and harmony.

Furthermore, Bradstreet refers to the Cadiz expedition of 1596, when Robert Devereux, the second Earl of Essex, and Charles Howard, who commanded the English fleet, destroyed the Spanish fleet and captured the city of Cadiz: "Her Essex took Cades, their herculean hold" (Bradstreet 46). The use of the possessive determiner "her," which demonstrates ownership, shows that Essex's victory in the Anglo-Spanish war was under the guidance of Elizabeth.

More interestingly, Elizabeth turned the sixteenth century gender conventions upside down by leading wars. She impressed them by her tenacity and shrewdness. Indeed, she is a queen of remarkable knowledge. Surprisingly, Bradstreet does not depict Elizabeth as a learned queen (307), although she was known for her superb humanist erudition, knowledge of philosophy, history, and theology, and proficiency in foreign languages such as French, Italian, Latin, and Greek. Elizabeth was also an accomplished author. Possibly, the poet's main concern is to accentuate female capabilities and excellence in two different fields traditionally occupied by men, underscoring Elizabeth's skill and shrewdness in politics and asserting her poetic talents. Many scholars such as Gim, Engberg, and Schweitzer agree that Bradstreet employed Elizabeth's reputation to gain credibility of her own poetic voice as a female poet, writing within a conventional Renaissance tradition rebuffing women's ability to write in public. This is what Gilbert and Gubar label the "anxiety of authorship" or the "thwarted desire for authorship" (xxxvii) in a male-dominated literary tradition. Schweitzer appropriately describes this as a "struggle for poetic identity and authority" (29394). Both Elizabeth and Bradstreet wanted their glory to be recognized, resisting all attempts to make their deeds invisible and silence their voices. The poet is seemingly claiming that they possess feminine qualities, as well as masculine attributes. Both have a strong determination to surpass the constraints placed 
by society and challenge disempowerment. Besides, she seems to be arguing that their words are mightier than any sword and that their wit is stronger than any misogyny. Perhaps she wants to make it clear that they are glorious because they do not seek male adoration, but that they deserve it nevertheless.

Both Elizabeth and Bradstreet endured misogyny, transcended gender-boundaries, and proved that the exercise of power and authorship are not male-limited. Indeed, both authority and authorship were new territories for women in early modern England. There is thus no wonder that the issue of femaleness and maleness is the main concern of the poet. It seems plausible to argue that the myth surrounding the character of Elizabeth is an instrumental device that allowed the poet to circumvent the constraints placed by males.

\section{Conclusion}

In analysing Bradstreet's rewriting of Elizabeth I's memory, we obtained a glimpse at her image of the imperious, ideal, and divine queen. She established a fantasy world in which Elizabeth's mythic dimension has been foregrounded. Unquestionably, Elizabeth remains an enigmatic character that is persistently a source of inspiration, partly because myth surrounded her life and her persona. Bradstreet enriches our knowledge of the posthumous representation of a powerful historical figure who ruled for nearly fifty years and is still a subject of academic inquiry. The poem, moreover, shows the importance and value placed on Elizabeth's memory as well as how it can potently be reused and reshaped. However, it is apparent that the real Elizabeth has not yet been accurately rendered as the range, complexity, and variety of mythological representations might suggest.

Using a mythological discourse, the poet has transformed Elizabeth into an icon or a model, a Protestant hero, a goddess, a maiden, and an immortal figure. She has enhanced Elizabeth's legend by highlighting the mythical images that she had encouraged when alive. Nonetheless, the ambiguity that shrouds the identity of Elizabeth demonstrates the complexity of the system of representation of an immense historical and cultural figure. This discourse, furthermore, illustrates the struggle to assert femaleness of both the monarch and the poet. Probing the poet's glorification of Elizabeth's reputation indicates the strength of her myths. She has become a fascinating, adorable model of female success. It is also evident that Bradstreet slavishly fashioned the pre-existing mythic im- 
ages that Elizabeth and her propaganda officials had already cast, notably as an incomparable monarch, a champion of Protestantism, and a warrior Queen.

Clearly then, mythical representation is an effective approach utilized to promote female competence. It indicates an interest in evaluating Elizabeth's persona and an obsession with her reputation. It also reveals that the gender of the poet influenced the way Elizabeth is elegiacally fashioned. Fascinated by her success, Bradstreet highlighted her political accomplishments, royal virtues, and unique qualities. This fascination is partly explained by Elizabeth's ability to transgress the overwhelming gender bias, claiming sovereignty and entering a male territory. Another possible explanation is that Elizabeth redefined masculinity and femininity and rejected male dominance. Indeed, she did not succumb to male authority, but she brilliantly affirmed her presence and central role as the true sovereign of England.

\section{Works Cited}

Alfar, Cristina León. Fantasies of Female Evil: The Dynamics of Gender and Power in Shakespearean Tragedy. U of Delaware P, 2003.

Bono, Paola. "Rewriting the Memory of a Queen: Dido, Cleopatra, Elizabeth I." European Journal of English Studies, vol. 10, no. 2, 2006, pp. 117-30.

Bradstreet, Anne. "In Honour of That High and Mighty Princess, Queen Elizabeth, of Most Happy Memory." The Transatlantic Feminisms in the Age of Revolutions, edited by Lisa L. Moore et al., Oxford UP, 2012, pp. 44-48.

Content, Rob. "Fair is Fowle: Interpreting Anti-Elizabethan Composite Portraiture." Dissing Elizabeth, Negative Representations of Gloriana, edited by Julia M. Walker, Duke UP, 1998, pp. 229-51.

Dobson, Michael, and Nicola J. Watson. England's Elizabeth: An Afterlife in Fame and Fantasy. Oxford UP, 2002.

Doran, Susan, and Thomas S. Freeman. "Introduction." The Myth of Elizabeth I, edited by Susan Doran and Thomas S. Freeman, Palgrave Macmillan, 2003, pp. 1-23.

Doty, William G. Myth: A Handbook. Greenwood Press, 2004.

Edson, Gray. Masks and Masking: Faces of Tradition and Belief Worldwide. McFarland, 2005.

Engberg, Kathrynn. S. The Right to Write: The Literary Politics of Anne Bradstreet and Phillis Wheatley. UP of America, 2010.

Ferguson, George W. Signs and Symbols in Christian Art. Oxford UP, 1959.

Ford, Elizabeth A., and Deborah C. Mitchell. Royal Portraits in Hollywood, Filming the Lives of Queens. UP of Kentucky, 2009.

Gilbert, Sandra. M, and Susan Gubar. The Madwoman in the Attic: The Woman Writer and the Nineteenth-Century Literary Imagination. 2nd ed., Yale UP, 2000. 
Gillespie, Katharine. Women Writing the English Republic, 1625-1681. Cambridge UP, 2017.

Gim, Lisa. “Representing the 'Phoenix Queen': Elizabeth I in Writings by Anna Maria van Schurman and Anne Bradstreet." Resurrecting Elizabeth in Seventeenth-Century England, edited by Elizabeth Hageman and Katherine Conway, Fairleigh Dickinson UP, 2007, pp. 168-84.

Goldring, Elizabeth, et al. John Nichols's The Progresses and Public Processions of Queen Elizabeth I: A New Edition of the Early Modern Sources. Volume IV: 1596 to 1603, Oxford UP, 2014.

Hackett, Helen. Virgin Mother, Maiden Queen: Elizabeth I and the Cult of the Virgin Mary, Macmillan Press LTD, 1995.

Heisch, Allison. "Queen Elizabeth I and the Persistence of Patriarchy." Feminist Review, vol. 4, 1980, pp. 45-56. JSTOR, www.jstor.org/stable/1394769. Accessed 12 Apr. 2020.

Hildebrand, Anne. “Anne Bradstreet's Quaternions and Contemplations." Early American Literature. U of Carolina P, vol. 8, no. 2, 1973, pp. 117-25.

Hutchins, Zach. "The Wisdom of Anne Bradstreet: Eschewing Eve and Emulating Elizabeth." Modern Language Studies, vol. 40, no. 1, 2010, pp. 38-59.

Jeffery, David L. A Dictionary of Biblical Tradition in English Literature, William. B. Eerdmans Publishing, 1992.

Knox, John. The First Blast of the Tempest against the Monstrous Regiment of Women. 1558. Reprinted in John Knox: On Rebellion, edited by Roger A. Mason. Cambridge Texts on History of Political Thought. Cambridge UP, 1994.

Latham, Robert. T. A Tale of Boxes: The Role of Myth in Creating and Changing our Stories. Wheatmark, 2009.

Marcus, Leah S., et al. Elizabeth I: Collected Works, U of Chicago P, 2000.

Prophet, Mark L., and Elizabeth Claire Prophet. The Masters and Their Retreats, edited by Annice Booth, Summit UP, 2003.

Ravenhill-Johnson, Annie, and Paula James. The Art and Ideology of the Trade: Union Emblem, 1850-1925. Anthem Press, 2014.

Schweitzer, Ivy. "Anne Bradstreet Wrestles with the Renaissance." Early American Literature, vol. 23, 1988, pp. 291-312.

Spenser, Edmund. The Faerie Queene, Book 1, with an Introduction by Carol V. Kaske. Hackett Publishing Company, 2006.

Watkins, John. Representing Elizabeth in Stuart England: Literature, History, Sovereignty. Cambridge UP, 2002.

Weber, John. An Illustrated Guide to the Lost Symbol. Sensei Publications LLC, 2009.

Williams, Deanne. “Dido, Queen of England.” ELH, vol. 73, no. 1, 2006, pp. 31-59. JSTOR, www.jstor.org/stable/i30029999. Accessed 2 Jan. 2020.

Williams, Raymond. Key Words: A Vocabulary of Culture and Society. Oxford UP, 1983. 


\title{
MITOLOGIZACIJA SJEĆANJA NA GLORIANU
}

\author{
Sažetak
}

\section{Sihem GARROUR I}

Odjel za jezikoslovlje i prevođenje

Sveučilište Northern Border

Rafha, Saudijska Arabija

sihem.garrouri@gmail.com

Razmatranje pjesme Anne Bradstreet „In Honour of That High and Mighty Princess, Queen Elizabeth, of Most Happy Memory“ (U čast Njezine Visosti moćne princeze, kraljice Elizabete, i najvedriju uspomenu, 1643.) skreće pozornost na presudnost mitskih slika u oblikovanju posmrtnoga ugleda Elizabete I. Analiza razotkriva načine na koje pjesma slavi uspomenu na Elizabetu I. te raspravlja o elegičnoj mitskoj rekonstrukciji njezina lika onim što je Schweitzer prikladno nazvao „rodnim poetskim glasom“(307). Rad pokazuje da se pjesnikinja pri oblikovanju Elizabetina posmrtnog lika snažno oslanja na mit te propituje taj mitološki prikaz posljednje vladarice tudorske dinastije s ciljem da pokaže kako žena-pjesnik preispisuje identitet žene-suverena. Pomna raščlamba različitih mitskih, elegičnih slika koje slave Elizabetu omogućava vrednovanje doprinosa stvaranju mita Anne Bradstreet. U radu se ispituju tri mitska prikaza: Elizabeta kao nenadmašni vođa, kraljica Feniks i amazonska kraljica ratnica.

Ključne riječi: Anne Bradstreet, Elizabeta I., glorifikacija, sjećanje, mit, reprezentacija 